\author{
THE TAX UNIT AND \\ HOUSEHOLD PRODUCTION
}

John Piggott

John Whalley

Working Paper No. 4820

\author{
NATIONAL BUREAU OF ECONOMIC RESEARCH \\ 1050 Massachusetts Avenue \\ Cambridge, MA 02138 \\ August 1994
}

We arc ;rateful to seminar groups at the Universiti : : of Melbourne, Sydney and Western Ontario for comments, and would like to thank Petar Vujanovich for outstanding research assistance, and Alan Powell and Alan Woodland for helpful discussions. This paper is part of NBER's research program in Public Economics. Any opinions expressed are those of the authors and not those of the National Bureau of Economic Research.

(C) 1994 by John Piggott and John Whalley. All rights reserved. Short sections of text, not to exceed two paragraphs, may be quoted without explicit permission provided that full credit, including () notice, is given to the source. 


\title{
THE TAX UNIT AND \\ HOUSEHOLD PRODUCTION
}

\begin{abstract}
The conventional wisdom is that taxing individuals rather than households is superior from an efficiency point of view under progressive income taxation. This is because it leads to secondary workers, whose labour supply elasticity is high, being taxed at a lower marginal rate than primary workers, whose labour supply elasticity is low. But once household production is taken into account, things are more complicated since tax design should also not distort the input use of family members' time in household production.

We use a simple general equilibrium model of household production parameterized using Australian data whose results clearly show that welfare effects can be either positive or negative when changing an existing income tax from an individual to a household basis. In so doing, we are able to investigate the comparative static effects of changing the tax unit from an individual to the household basis in a richer model than that used thus far in the literature, since we capture both Ramsey considerations from differential labour supply elasticities, and factor input distortions into household production. Our results challenge conventional wisdom, and suggest that household unit taxation deserves more sympathetic consideration than is currently the case.
\end{abstract}

John Piggott School of Economics University of New South Wales Sydney, New South Wales AUSTRALIA
John Whalley Department of Economics University of Western Ontario London, Ontario

CANADA and NBER 


\section{INTRODUCTION}

Whether the income tax should apply to individuals or households has been an issue in public finance ever since the tax was introduced. Early arguments centred on notions of equity and tax-neutrality with respect to marriage decisions.' But since Boskin (1973) (and later Boskin and Sheshinski (1983), an efficiency argument in favour of using the individual as the tax unit has been widely accepted. ${ }^{2}$ A simple Ramsey (1927) rule (ignoring cross elasticities) suggests that an individual with a high labour supply elasticity should face a lower marginal tax rate than one with a low elasticity. Econometric estimates of labcur supply elasticities are higher for secondary than for primary workers. Given that secondary workers on average earn less than primary workers, taxing individuals under the income tax with a progressive rate structure is superior from an efficiency point of view, whereas household based taxes are not. ${ }^{3}$

In this paper we argue that this conventional wisdom is more fragile than has been previously portrayed in the literature. This is because taxing on an individual basis under a progressive income tax also distorts the primary-secondary

\footnotetext{
'Bittker (1975) traces the development of U.S. income tax legislation with respect to the tax unit.

${ }^{2}$ This argument is also either asserted or derived from an explicit model in Rosen (1976, 1977, 1978); Brazer (1980); and Munnell (1980).

${ }^{3}$ Beyond these efficiency considerations in the choice of tax unit, there does not appear to be any clear relationship between progressivity and the tax unit asserted in the literature. Kakwani (1977), for instance, compares the progressivity (with respect to individuals) of the Australian, Canadian, U.K. and U.S. systems, of which the first two at the time had individual filing. He found the U.K. system to be the most progressive and the U.S. system least progressive.
} 
worker input ratio in household production. In a model with market and household (non-market) production and with primary and secondary labour, individual-based taxes imply a distortion of input decisions by primary and secondary workers into household production. The costs of this distortion can outweigh the benefits of setting different tax rates for individual members to reflect market labour supply elasticities. Two effects - differential labour supply elasticities and distortions in household production - rather than one, need to be taken into account in evaluating the choice of tax unit.

To analyze how the incorporation of household production affects the choice of tax unit, we use a numerical general equilibrium model since an analytical formulation of the comparison across tax units is not tractable for the cases we discuss later. Numerical simulation we view as inevitable if richer models than have thus far been used in analytical literature are to be employed. The model incorporates market and household production, each of which use primary and secondary labour as inputs. It is parameterized using Australian data drawn from time use surveys covering married couples. We use the model in counterfactual mode to evaluate income taxes based on alternative tax units.

Our results show that, depending upon values of labour supply and other elasticities to which the model is calibrated, and the form of household unit used, a switch from an individual to a household basis can lead either to an aggregate welfare gain or loss; although gains are the more common outcome across the cases we consider. Model results thus provide clear counter-examples to the 
current presumption in favour of individual-based taxation outlined above, and suggest household taxation could more likely be preferred.

\section{A SIMPLE GENERAL-EQUILIBRIUM MODEL WITH MARKET AND HOUSEHOLD PRODUCTION}

To investigate how incorporating household production changes the conventional analysis of the choice of tax unit, we use a simple applied generalequilibrium model with two factors of production, primary and secondary labour ( $L^{P}$ and $L^{S}$ ). These are inputs in the production of both a single market good, $M$, and a vector of household-specific non-market goods, $N$. There is no trade in nonmarket goods, and the non-market good consumed by each household is produced using only the labour supplied by members of that household.

We keep the model structure parsimonious so as to explore the tax unit issue in as transparent a structure as possible. Because trade occurs between households in the market good, we consider a two-household model formulation as our central case. This, however, allows for redistribution between households under tax unit changes; and to abstract from this, in sensitivity analyses we also consider a one-household (or identical households) version of the model. We also consider a one-household version of the model without household production to confirm that the model supports conventional wisdom without the extra household production component we emphasize above. 
Each of the two household types identified in the central case variant of the model is assumed to comprise two individuals, one of which is endowed with primary labour, and the other with secondary labour. These endowments are allocated by these individuals between market supply, non-market production and leisure, the last of which takes the form of direct consumption of the corresponding labour type. The household division most easily available from the data we use is of two adult household groups, one with and the other without children. This also has the advantage of generating household groups with differing market supplies of secondary labour in the data.

Figure 1 outlines how labour allocation and market and non-market production enters the central case variant of the model. There are two households, two labour types (primary and secondary), and two forms of production (market and household). Because each household cannot supply more than their own labour for the production of their own household good, labour types by household need to be separately identified. Hence, labour types supplied to the market by the two households are combined into composite labour-type inputs (primary and secondary) for market production; if the substitution elasticities here are high, effectively homogeneous labour types occur for market production." Using this formulation also helps in the later analysis of alternative tax schemes.

\footnotetext{
"Our later model simulations use high values of 25.0 for these elasticities: which approximates a treatment of homogeneity across each of the two labour types supplied to the market by the two households.
} 


\section{FIGURE 1}

Structure of the General Equilibrium Household Production Model ( 2 households; 2 household-specific non-market goods; 1 market good)

Markes Activity
Labour Endowments
Non-marker

Activity

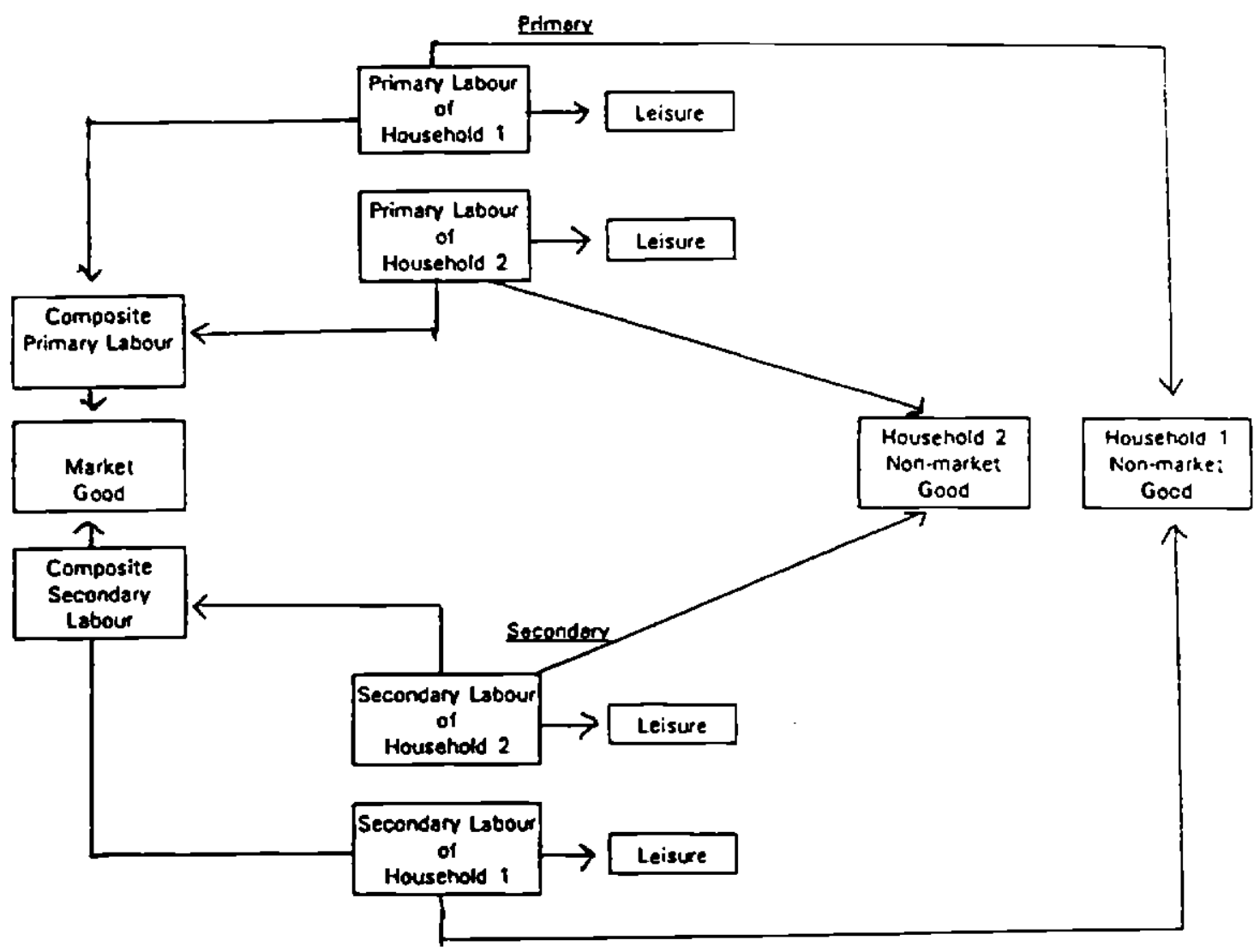


6

since each individual's labour income can then be taxed either at a separate (individual) rate or at a combined household rate in different model simulations.

More formally, the labour endowments $(\bar{L})$ of primary $(P)$ and secondary (S) labour of the households, $h,\left(\bar{L}_{h}^{p}, \bar{L}_{h}^{\prime}\right)$ are allocated to market labour supply $\left(L_{h}^{p}, L_{h}^{*}\right)$, non-market labour supply $\left(W_{h}^{p}, W_{h}^{s}\right)$, and leisure $\left(E_{h}^{p}, E_{h}^{s}\right)$. Each household is assumed to maximize a utility function

$$
U_{h}=U_{h}\left(E_{h}^{p}, E_{h}^{s}, M_{h}, N_{h}\right)
$$

subject to a household income constraint and separate time constraints for the labour types within the household. $E_{h}^{p}$ and $E_{h}^{s}$ represent leisure consumed by primary and secondary workers in the household, $M_{h}$ is the household consumption of the market good, and $N_{h}$ is the $h^{\text {th }}$ household's non-market good consumption. We use nested CES utility functions to represent (1).

On the production side, the market good, $M$, is produced according to a constant returns to scale CES function,

$$
M=M\left(L^{\circ}, L^{\prime}\right)
$$

where $L^{\rho}$ and $L^{s}$ are the market supply of primary and secondary labour, aggregated across households.

$L^{\rho}$ and $L^{s}$ are, in turn, CES aggregates of the market supplies of the household labour types:

$$
\begin{aligned}
& L^{P}=L^{P}\left(L_{1}^{p}, L_{2}^{p}\right) \\
& L^{*}=L^{P}\left(L_{1}^{p}, L_{2}^{*}\right)
\end{aligned}
$$


as discussed above.

Each household also produces its own non-market good, $N_{h}$, with production also characterized by a constant returns CES function:

$$
N_{h}=N_{h}\left(W_{h}^{p}, W_{h}^{s}\right), h=1,2
$$

Equilibrium in a no-tax version of the model is given by wage rates for the two composite labour types (primary and secondary), and a price for the market good, such that

(i) Demand equals supply for the market good, and

$$
\sum_{h} M_{h}=M
$$

(ii) Time allocation constraints hold by labour type by household,

$$
\begin{array}{ll}
\bar{L}_{h}^{p}=E_{h}^{p}+L_{h}^{p}+W_{h}^{p} & , h=1,2 \\
\bar{L}_{h}^{*}=E_{h}^{s}+L_{h}^{*}+W_{h}^{s} & . h=1,2
\end{array}
$$

where the superscripts $P$ and $S$ refer to primary and secondary labour. Market factor supplies, $L_{h}^{p}, L_{h}^{\infty}$ and the non-market factor inputs for each household will satisfy Pareto efficiency conditions given in the no-tax case, equilibrium prices for primary and secondary labour and the market good. Thus, in effect, the nonmarket segment of the model operates as a fully priced competitive sub-system for 
each household, allowing the whole model to be solved using general equilibrium computational techniques (see Shoven and Whalley (1992)).

Income taxes are introduced into the model on either an individual or household basis, using the general equilibrium tax structure set out in Shoven and Whalley (1973, 1992). For simplicity, we return all tax revenues to the households paying income taxes as lump sum transfers, with weights reflecting the taxes they pay under the income tax in the base-case equilibrium data. As in Shoven and Whalley (1973), in the presence of taxes government budget balance holds in equilibrium. We parameterize the model using calibration to a benchmark equilibrium data set (see Mansur and Whalley (1984)), using the model, in turn, to perform counterfactual equilibrium analyses under different tax arrangements. Calibration reflects the requirement that when used in the model, the parameter values generated yield an equilibrium solution to the model which replicates benchmark data.

The benchmark equilibrium data set we use builds on information collected in a time use survey of Australian households conducted in 1974 as a companion to a wider Multinational Time Budget Studies program. ${ }^{5}$ Table 1 reports average household time allocations throughout the day from this survey for each adult in the two main household types in the model. This information is then combined

\footnotetext{
${ }^{5}$ See Juster and Stafford (1991) for a recent survey of time use studies in other countries.
} 


\section{TABLE 1}

The Allocation of Daily Time Among Alternative Uses by Household Type, Australia, 1974

$\begin{array}{llcccc}\begin{array}{l}\text { Household } \\ \text { Type }\end{array} & \begin{array}{c}\text { Household } \\ \text { Member }\end{array} & \begin{array}{c}\text { Market } \\ \text { Labour }\end{array} & \begin{array}{c}\text { Non-market } \\ \text { Labour }^{3}\end{array} & \text { Leisure }^{4} & \text { Total }^{5} \\ \begin{array}{l}\text { Type 1 } \\ \text { (with children) }\end{array} & \text { Primary } & 7.7 & 1.1 & 4.2 & 13.0 \\ & \text { Secondary } & 1.5 & 4.5 & 4.4 & 10.4 \\ \begin{array}{l}\text { Type 2 } \\ \text { (no children) }\end{array} & \text { Primary } & 6.2 & 1.4 & 5.1 & 12.7 \\ & \text { Secondary } & 1.7 & 4.4 & 5.6 & 11.7\end{array}$

Source: McNair Anderșon Associates (1974).

1. Household 1 has dependent children; household 2 does not.

2. Includes travel time to and from work, and regular breaks (lunch, etc.).

3. Includes "domestic work", "care of children", and "purchase of goods and services".

4. Includes "social activities and entertainment", "active leisure" and "passive leisure".

5. The amount of time not allocated to the categories listed in notes 2-4 varies between household members and across households. We assume this to be non-discretionary time; this does not enter explicitly into the calculations using our model. 
with data on 1973-74 Australian tax rates ${ }^{6}$, and survey data on component household incomes to provide the input benchmark equilibrium data for model calibration.

The income, consumption, and tax data used as the benchmark for the model are given in Table 2. Consumption data in Table 2 reflects both information from Table 1 and conditions that market good purchases equal money income for each household, and that non-market consumption exhausts non-market production, since non-market goods for each household are, by assumption, not traded. By construction, all model equilibrium conditions are satisfied in this data set.

Figure 2 sets out the nesting structure used in household preferences in the model, and Table 3 sets out both the elasticity specification used in the central case variant of the model, as well as the model sensitivity variants we consider later. We later consider both structural and parametric sensitivity analyses with the model; with the former focusing on model variants first with only one household, and then without household production.

\footnotetext{
'See Australia (1975), 0.63.
} 


\section{IABLE 2}

\section{Benchmark Data on Household and Individual Incomes (including transfers). Personal Taxes and Production used in the Model \\ (1974 data for Australia in A\$)}

A. Income and Tax Data

(1)

Gross of
Tax Income
from Paid
Work
$\$$

Type 1

(with children)

$\begin{array}{lll}\text { Primary } & 6901 & 1 \\ \text { Secondary } & 925 & 11621\end{array}$

Type 2

(no children)

$\begin{array}{ll}\text { Primary } & 5527 \\ \text { Secondary } & 1279\end{array}$

(2)

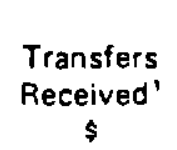

11621

$\int_{1}^{1156}$

(3)

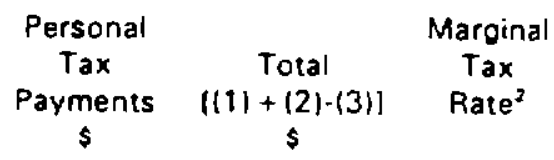

(5)

(4)

$\begin{array}{cll}1592 & 1 & 37.9 \% \\ 29 & 17826 & 4.9 \%\end{array}$

$\begin{array}{ll}1091 & 1 \\ 65 & 16802\end{array}$

$33.3 \%$

$7.2 \%$

\section{B. Consumption Data}

$\begin{array}{lcccc}\begin{array}{l}\text { Household } \\ \text { Type }\end{array} & \begin{array}{c}\text { Market } \\ \text { Good }\end{array} & \begin{array}{c}\text { Non-market } \\ \text { Good }\end{array} & \begin{array}{l}\text { Primary } \\ \text { Worker } \\ \text { Leisure }\end{array} & \begin{array}{c}\text { Secondary } \\ \text { Worker } \\ \text { Leisure }\end{array} \\ \begin{array}{l}\text { Type } 1 \text { (with children) } \\ \text { Type 2 (no children) }\end{array} & 7826 & 3258 & 2338 & 2587 \\ & 6806 & 3904 & 3030 & 3910\end{array}$

1. In the benchmark data, total transfers received equal taxes paid for consistency with oovernment budget balance.

2. For primary workers, this is the tax rate associated with the average income for each household type. For secondary workers, this is a weighted average of the average of the tax rates for secondary workers and a zero rate for non-labour-market participants. 


\section{Figure 2}

Nesting Structure Used in

Household Preferences

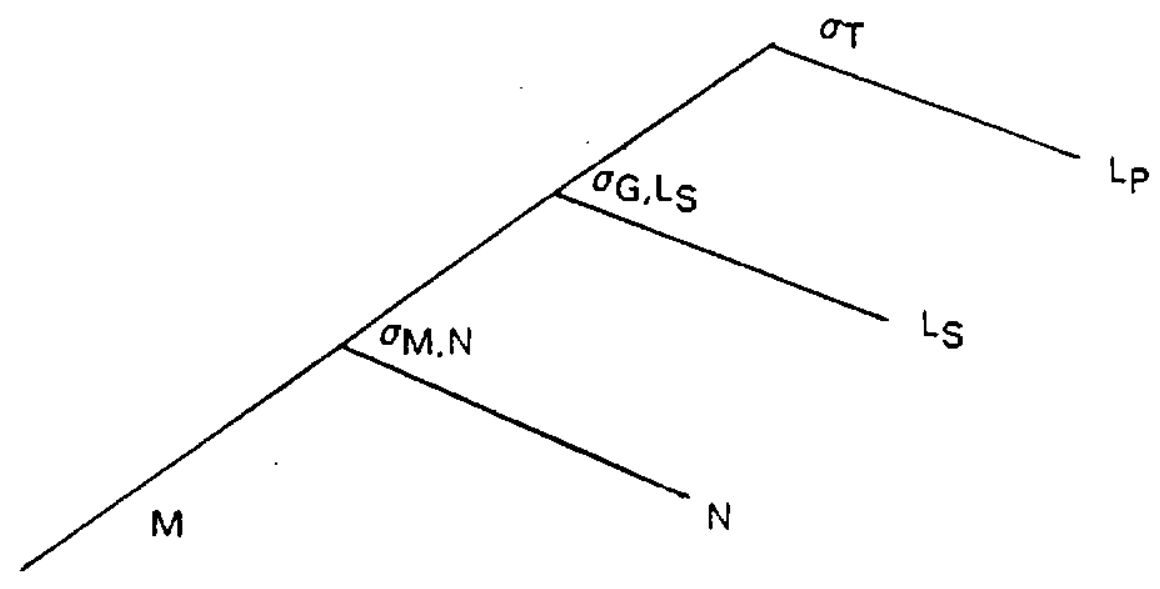




\section{IABLE 3}

\section{Central Case Elasticity Specification and Model and Elasticity} Variants used in Sensitivity Analysis
A. Central Case

\section{Demand Side}
Household 1 (no children)
Household 2 (with children)
Production Side

$\begin{array}{cll}\sigma_{T} & \sigma_{G . L} . & \sigma_{M, N} \\ 0.1 & 0.15 & 0.5 \\ 0.1 & 0.4 & 0.5 \\ \sigma_{M} & \sigma_{L \cdot} & \sigma_{L} \cdot\end{array}$

Labour Supply Elassticities (no children)
$1.5 \quad$ High (25.0)

High (25.0)
Household 2 (with children)
Primary
0.1
0.1
1.5

B. Structural Sensitivity Variants

Varians

1. Equivalent Single Household model

2. Equivalent Single Household model with no household production

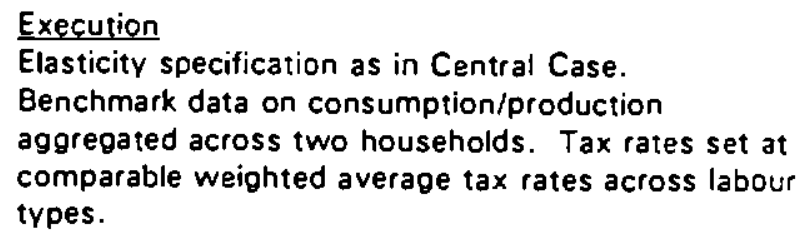
types.
As above for equivalent single household model, with, in addition, benchmark data on household production and inputs of primary and secondary labour reallocated as leisure consumption. This effectively removes household production from the model.

\section{Elasticity Sensitivity Varionts}

1. Alternative values of production side elasticities $\sigma_{M}, \sigma_{N}$ considered in combination.

2. Combinations of demand side elasticities $\sigma_{M, N}$ which vary by household.

3. Changes in implied uncompensated labour supply elasticities used in model calibration. 
The elasticity values used in calibrating the model draw largely on econometric studies of labour supply, our procedure being to choose model parameters lelasticities of substitution in preferences, and substitution elasticities in household production) so as to be consistent with literature-based labour supply elasticities. In our calibration, we place major stress on these elasticities since these have been central to previous arguments in favour of individual-based taxation.

Over the years, studies have produced a wide range of elasticity estimates for both primary and secondary labour, with estimates sensitive to both data and econometric procedure; Killingsworth (1983) and Killingsworth and Heckman (1986) both provide comprehensive surveys. For primary workers, our calibration assumes uncompensated labour supply elasticities of 0.1 across our household types and, for secondary workers, elasticity values of 1.5 , comparable to those reported in the most recent Australian study for the total supply elasticity (that is, hours and participationl; due to Ross (1986). This study uses a methodology close to that which Killingsworth (1983) terms "second-generation," taking account of sample selection bias introduced by non-participation. It, therefore, tends to yield somewhat higher elasticity estimates than those of earlier studies.

Estimates of substitution elasticities in production are also important for our analysis, and are parametrically varied since direct empirical estimates are unavailable. We use central-case elasticity values of 1.5 in both market and nonmarket production, rationalized (somewhat indirectly) by noting that capital labour 
substitution elasticities in aggregate production functions differ approximately by a factor of two depending both upon whether cross-section or time series estimation is used, and the estimating equation (see Berndt (1976)). Higher values of around 1.0 are obtained for cross section. Our use of 1.5 in our central case reflects the argument that substitution between labour types is likely easier than between capital and labour.

Two issues in using labour supply elasticity estimates in calibrating the model are worthy of comment in passing, since these seem not to have been noted previously in the literature. The first is that because the calibration procedure used in the model requires that the model labour market supply response for a small change in the wage be consistent with literature elasticity estimates, at least three different forms of calibration can be used. The appropriate wage could be increased holding all other prices fixed; the wage could be increased, and prices allowed to adjust to satisfy zero profit conditions; or the wage could be allowed to change as a result of a shock to the model (such as a change in a tax rate) and a new equilibrium computed.

The third of these is sharply divergent from current econometric methodology, which only estimates preferences of the individual or household in a partial equilibrium framework. The choice between the first two depends upon the expectations assumed for households in the sample under study. If a household does not anticipate that a wage change will be reflected in prices, then the first formulation is appropriate (this is the procedure that most econometric studies 
use). If, on the other hand, households anticipate that a wage increase they receive will be reflected in price increases, then the second formulation appears more suitable. In our procedure, we calibrate parameters of household utility functions to labour supply elasticities, assuming that households recognize the change in the opportunity cost (or imputed price) of non-market supplied labour resulting from a wage change, but do not expect any resulting indirect changes in the price of the market good.

The second point is that in most calibration exercises, elasticities of substitution between goods and leisure in the household demand functions are directly determined by the labour supply elasticity and budget share data used in calibration. In the model used here, however, this information will only determine combinations of household preference and production substitution parameters, since choices about the supply of labour to the market will be influenced by the household production technology as well as by household preferences. This is one reason we perform parametric sensitivity analyses with the models in generating the results discussed later.

In concluding this section, it should aiso be noted that several potentially complicating factors are ignored in the model. These include taxes other than personal taxes; the incorporation of non-married couple households and singleperson households, both of which raise the question of how rate structures should 
be differentiated by marital status; and endogenous family formation. ${ }^{7}$ These complicate the analysis if analyzed simultaneously within the structure we use, and so we ignore them. Similarly, introducing capital into the model raises further questions, including the tax treatment of owner-occupier housing and its role in household production.

\section{MODEL RESULTS AND THEIR IMPLICATIONS}

We have performed a number of experiments with our model, each designed to explore the implications of moving from an individual basis in the income tax las in the base-case datal to an alternative household based tax unit. In each experiment, an equilibrium under a new tax regime is computed and benchmark and counterfactual equilibria compared. The net revenue yield is preserved in real terms in the new equilibrium, and as in !ne benchmark, revenues are passed back to households in the form of transfers. The value of transfers received by each household is thus held constant in real terms between the benchmark and replacement equilibria.

We consider three alternative household-based income tax arrangements. each of which represents a different way of changing the individual unit prevailing

'See Haurin, Hendershott and Kim (1993) for a recent discussion of this issue, and Feenberg and Rosen (1994) for recent discussion of the related issue of the marriage tax. 
in the benchmark case to a household unit. ${ }^{*}$ In each case, household unit treatment involves both members of the household facing the same marginal tax rate. Household production-based efficiency considerations are removed by the choice of tax unit in all three of these cases because differences in marginal rates across household members are removed. Cases thus differ in how these common marginal tax rates are set.

In the first, the existing legal income tax structure the Australian income tax in 1974) is applied to combined household income rather than individual income. As this is a progressive tax, it retains the same rate structure as the benchmark individual-based tax, and hence marginal tax rates on combined income exceed those on separate individual incomes. In implementing this household unit tax replacement in the model, we make further proportional adjustments to both average and marginal tax rates for each rousehold type relative to the base case so as to preserve revenue neutrality.

In the second case, we allow household members to split their income equally for tax purposes, and apply the existing (Australia, 1974) rate schedule to each. This achieves an outcome in which members of the household face the same marginal tax rate, but with a progressive base-case tax, rates are lower than in the first case. This "income averaging" treatment also differs from the "existing

\footnotetext{
${ }^{9}$ The base-case equilibrium is as reflected in Australian data, and hence while having considerably different marginal tax rates for primary and secondary labour within each household, does not necessarily correspond to a setting of optimal tax rates by household.
} 
schedule" tax unit charge of the first case, in that the ratio of the marginal to the average tax rate is different across members of the household. ${ }^{9}$ In this case, tax schedules by household are again scaled to preserve tax yield.

In the third case, we no longer use existing rate schedules to move to a household unit, and instead use marginal tax rate equivalence as the basis for household unit replacement. In this, we use the weights of market incomes of primary and secondary labour in benchmark data to compute a weighted average household marginal tax rate which we use as the household unit tax replacement. This procedure is used to remove variations in the level at which marginal tax rates are set as part of the tax unit change. In these cases, final tax rates are again also determined by a scaling to achieve revenue neutrality.

Table 4 reports welfare impacts from these three tax unit changes for the central case variant of the model. We report Hicksian equivalent variations both by household and aggregated across housenolds. ${ }^{10}$ Their striking feature is that the aggregate welfare measure, the sum of EVs across households, is negative for the existing schedule case and positive for the income averaging case. As these both relate to tax unit changes using existing (1974) tax schedules, the outcomes across cases 1 and 2 are consistent with the pattern of marginal rate changes

${ }^{9}$ This ratio was proposed by Slitor (1948) as a measure of tax progressivity, but as Kakwani (1977) points out, this measure is also sensitive to the point on the schedule being considered.

${ }^{10}$ As Kay (1980) has pointed out, multiple equilibria comparisons are more easily carried out using EVs rather than CVs, because the same set of "old" prices is used for all calculations. 
TABLE 4

Welfare Implications of Adopting the Household as the Taxation Unit in the Model

\begin{tabular}{l} 
Household 1' \\
Equivalent \\
Variation \\
\hline
\end{tabular}

$\begin{array}{cc}\text { Household } 2^{3} & \text { Total } \\ \text { Equivalent } & \text { Equivalent } \\ \text { Variation } & \text { Variation }\end{array}$

\section{A. Centrol Case Results}

1. Applying Existing Tax Schedule to combined household income (with scaling for equal yield')

$$
\begin{aligned}
& \text { As (1974) } \\
& \text { as } \% \text { of income }
\end{aligned}
$$$$
-3.1
$$

$-65.9$

2. Income Averaging Within Households (with scaling for equal yield')

$$
\begin{aligned}
& \text { As }(1974) \text {. } \\
& \text { as } \% \text { of income }
\end{aligned}
$$

$-7.0$

$(-0.04)$

56.8

3. Equivalent Marginal Tax Rate Household Base Regime (with scaling for equal yield')

$$
\text { As }(1974)
$$

as $\%$ of income

$(-0.18)$

34.5

10.201

8.4

10.031

- Both average and marginal rates in the replacement income tax structure are proportionally adjusted to ensure equality of tax yield in the replacement.

2 These are money metric measures of welfare changes between equilibria, calculated as Hicksian equivalent variations.

3ousehold 1 has no children; Household 2 is with children. 
discussed above. Table 4 also reports results for equivalent marginal tax rate changes which also show an aggregate gain. Taken in combination, and in particular with the change in sign across tax replacements, these results therefore challenge the conventional wisdom, emphasized in the introduction, that the individual tax unit is to be preferred to the household unit on efficiency grounds.

Effects across households suggest that gains are also larger, or losses are smaller, in the first two cases for the no-child households who supply more secondary labour to the market. This result is reversed under the equivalent marginal tax rate change, since with proportional equal-yield scaling in this case they pay more taxes. Hence, legal and marginal rate tax unit changes differ in this respect.

Because the movements between individual and household tax units based on existing (1974) tax schedules in Table 4 involve different changes in marginal tax rates which differ, and hence affect the overall gain or loss from the switch between tax units, we have also performed a series of model sensitivity runs. For simplicity of presentation, these are all performed on a marginal rate equivalent basis, " with results reported in Table 5 . We also use these runs as a basis for exploring the sensitivity of results to model structure by moving to a onehousehold model, and then also removing household production.

\footnotetext{
"As we explain above, these cases preserve weighted average marginal tax rates and hence equivalent labour supply distortions.
} 
TABLE 5

Model Structure Comparisons Using Marginal

Tax Rate Equivalent Model Runs

Welfare Impact of Adopting Equivalent Household

Marginal Tax Rate' (Hicksian EVs in 1974\$)

\section{Medel Form ${ }^{2}$}

1. Central Case $(2$ household, with household production)

8.4

2. 1 Household model, with household production

3.57

$(0.01 \%)$

3. 1 Household model, without household production

$-30.0$

$(-0.14 \%)$

- Calculated using incomes of labour types in benchmark data as weights.

2 The three model variants maintain parametric comparability by calibrating to the same labour supply elasticities, and similar substitution elasticities elsewhere in the model. 
In Table 5, results reiterate the aggregate gains in moving to a household tax unit on a marginal rate equivalent basis as in Table 4, reflecting the presence of household production distortions under an individually based income tax. The size of the gain is little different in an equivalent one rather than two-household model, suggesting that efficiency aspects of the tax change are little affected by interhousehold income distribution effects in the two-household model. But gains become losses in the no-household production model, since distortions of household production are absent. This confirms the intuition we stress above as to the effects of household production on the tax unit issue.

The size of the aggregate welfare change when moving from an individual to a household basis in these cases depends not only on the form of the tax replacement, the parameter specification used in the model is also important. The role of a number of key parameters in our earlier result is explored in results reported in Table 6. Results in Cases 1,2 and 3 of Panel A, jointly suggest that variations in the market production substitution elasticities $\left(\sigma_{M}\right)$ have little impact on aggregate welfare effects, while there is considerably more sensitivity to changes in household production elasticities $\left(\sigma_{N}\right)$. This corresponds with the intuition above that it is household production effects which are key to any challenge to conventional analysis of individual versus household tax unit issues. Results in Panel 8 show increasing losses for existing schedule changes as $\sigma_{M, N}$ is both sset at higher values for households with no children and increased. 
TABLE 6

Sensitivity of Central Case Model Results

to Elasticity Changes

A. Joint Sensitlvity to Market and Non-Market Production Elasticity Changes

1. Welfare Impacts' of Applying Existing

Tax Schedule to Combined Household Income

(as in Table 4)

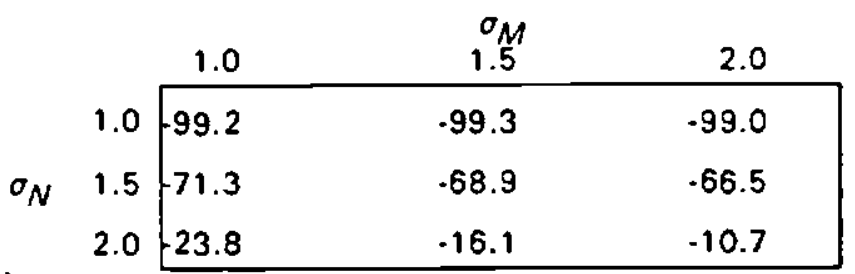

2. Welfare Impacts' of Income Averaging

Within Households

(as in Table 4)

3. Welfare Impacts' of Equivalent Marginal

\begin{tabular}{|c|c|c|c|}
\hline & 1.0 & $\begin{array}{c}\sigma_{M} \\
1.5\end{array}$ & 2.0 \\
\hline 1.0 & 50.7 & 50.8 & 50.8 \\
\hline$N \quad .1 .5$ & 54.5 & 56.8 & 58.4 \\
\hline 2.0 & 58.6 & 65.0 & 69.8 \\
\hline
\end{tabular}

Tax Rates Regime

(as in Table 4)

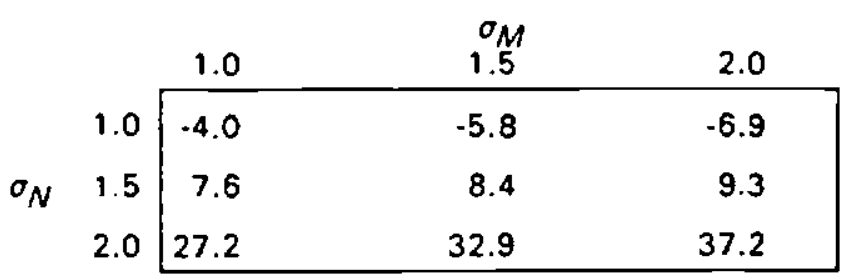

B. Vorrine Substitution Elasticities in Preferences Between Market and Non-Market Goods Across Households

1. Existing Scheduie Replacements ${ }^{2}$ (higher elasticities for households with children')

\begin{tabular}{ccc|}
$\begin{array}{c}\text { Household I } \\
\text { (No children) } \\
\sigma_{u . N}\end{array}$ & $\begin{array}{c}\text { Household 2 } \\
\text { (With childron) } \\
\sigma_{m . N}\end{array}$ & $\begin{array}{c}\text { Aogregato } \\
\text { Well ore Impoct }\end{array}$ \\
\hline 0.3 & 0.5 & -58.0 \\
0.5 & 0.5 & -68.9 \\
0.5 & 0.7 & .83 .6 \\
\hline
\end{tabular}

These ore Hicksion oquivalent variations in As 1974: see Footnote 2 10 Table 4.

Soe text for explenetion.

In the Central Cose $\sigma_{m, n}=0.5$ tor both households. 


\section{CONCLUSION}

Conventional wisdom suggests that taxing individuals rather than households under progressive income taxes is superior from an efficiency point of view, since this will lead to secondary workers, whose labour supply elasticity is high, being taxed at a lower marginal rate than primary workers, whose labour supply elasticity is low. We suggest that household production also needs to be taken into account, since not distorting input decisions by family members in household production instead suggests taxing on a household not an individual basis.

Here we use a general equilibrium model of household production parameterized using Australian data to investigate the comparative static effects of changing the tax unit from an individual to a household basis in a richer model than used thus far in the literature. Our results clearly challenge conventional wisdom. In our central-case model results, welfare effects from changing the income tax from an individual unit to a household unit basis can be positive or negative, depending on the replacement tax regime and the elasticity parameters chosen for the model. This is because of tax distortions of household production neglected in previous literature.

We also find that when the existing tax regime is maintained, changing to a household basis from an individual basis is more likely to be a welfare-gaining proposition under a higher production elasticity specification. Households providing relatively more secondary labour to the market tend to fare better, since 
they benefit from the elimination of dispersion in marginal tax rates. Simulations carried out for alternative elasticity specifications give further insights on how changes in substitution parameters in demand and household production affect these results.

The model we use is highly stylized in a number of ways. It ignores nonmarried couple households and income from capital. It also treats the househcid as a single optimizing agent, when in fact the behaviour and preferences of individuals within the household also have considerable influence over household behaviour. We also ignore effects on endogeous family formation, which in practice are likely to be important. Nevertheless, our model results strongly suggest that the superiority of the individual tax unit on efficiency grounds may not be as clearly established as existing literature seems to suggest. 


\section{REFERENCES}

Berndt, E.R. (1976). "Reconciling Alternative Estimates of the Elasticity of Substitution." The Review of Economics and Statistics, Vol.58 (February), pp.59-68.

Bittker, B. (1975). "Federal Income Taxation and the Family." Stanford Law Review, 27, pp.1389-1463.

Boskin, M.J. (1975). "Efficiency Aspects of the Differential Tax Treatment of Market and Household Economic Activity." Centre for Research in Economic Growth, 20, pp.281-297.

Boskin, M.J. and Sheshinski, E. (1973). "Optimal Tax Treatment of the Family." Memo 143, Centre for Research in Economic Growth, Stanford University.

Boskin, M.J. and Sheșinski, E. (1983). "Optimal Tax Treatment of the FamilyMarried Couples." Journal of Public Economics, 20, pp.281-297.

Brazer, H.E. (1980). "Income Tax Treatment of the Family" in Aaron, H. and Boskin, M. (eds.). The Economics of Taxation. The Brookings Institution. pp.223-246.

Feenberg, D. and H. Rosen (1994). "Recent Developments in the Marriage Tax." NBER Working Paper 4705. April. National Bureau of Economic Research, Cambridge, Massachusetts.

Haurin, D.R., P.H. Hendershott, and D. Kim (1993). "The Impact of Real Rents and Wages on Household Formation." The Review of Economics and Statistics, Vol.LXXV, No.2, May, pp.284-293.

Juster, F.J. and F.P. Stafford (1991). "The Allocation of Time: Empirical Findings, Behavioural Models, and Problems of Measurement." Journal of Economic Literature, Vol.XXIX, June, pp.471-522.

Kay, J. (1980). "The Deadweight Loss from a Tax System." Journal of Public Economics, Vol.13, No.1, pp.111-120.

Killingsworth, M.R. (1983). Labor Supp/y, Cambridge University Press.

Killingsworth, M.R. and J. Heckman (1986). "Female Labor Supply: A Survey" in O. Achenfelter and R. Layard (eds.), Handbook of Labor Economics, Vol.1. pp.103-204. North-Holland, Amsterdam, New York. 
Kakwani, N. (1977), "Measurement of Tax Progressivity - An International Comparison." Economic Journal, March, pp.71-80.

Munnel, A. (1980). "The Couple versus the Individual under the Federal Personal Income Tax" in Aaron, H. and Boskin, M. (eds.), op. cit.

McNair Anderson Associates (1974). Australian's Use of Time, Albury-Wodonga and Melbourne, 1974.

Ramsey, F.J. (1927). "A Contribution to the Theory of Taxation." Economic Journal, March, 37, pp.47-61.

Rosen, H. (1976). "A Methodology for Examining Tax Reform Proposals." Journal of Public Economics, 6, pp.105-121.

Rosen, H. (1977). "Is it time to abandon joint filing?" National Tax Journal, December, pp.423-428.

Rosen, H. (1978). "The Measurement of Excess Burden with Explicit Utility Functions." Journal of Political Economy, April, pp.S121-S135.

Ross, R. (1986). "Analysis of the 1980 Sydney Survey of Work Patterns of Married Women: Further Results." Economic Record, 62, September, pp.325. 337.

Shoven, J. and J. Whalley (1973). "General Equilibrium with Taxes; A Computational Procedure and an Existence Proof." Review of Economic Studies, Vol.XL, No.124 (October), pp.475-489.

Shoven, J. and J. Whalley (1992). Applying General Equilibrium. Cambridge University Press.

Slitor, R. (1948). "The Measurement of Progressivity and Built-in Flexibility." Quarterly Journal of Economics, 62, pp.309-313.

Wales, T.J. and Woodland, A.D. (1976). "Estimation of Household Utility Functions and Labor Supply Response." International Economic Review. Vol.17, No.2, pp.397-410.

Wales, T.J. and Woodland, A.D. (1977). "Estimation of the Allocation of Time for Work, Leisure, and Housework." Econometrica, Vol.45, No.1, pp.115-132. 